\title{
Species diversity and altitudinal preferences of lichens on selected substrata in Ritigala Strict Natural Reserve
}

\author{
KW Gunawardene ${ }^{1}$ and SC Wijeyaratne $e^{2 *}$ \\ ${ }^{I}$ Department of Forestry and Environmental Science, Faculty of Applied Sciences, University of Sri Jayewardenepura, Nugegoda. \\ ${ }^{2}$ Faculty of Applied Sciences, University of Sri Jayewardenepura, Nugegoda.
}

\begin{abstract}
The objective of this research was to study corticolous and saxicolous lichen diversity and distribution in Ritigala Strict Natural Reserve (SNR). For this survey, 34 plots, covering different forest types at different elevations: $<300 \mathrm{~m}$, between $300 \mathrm{~m}$ and $500 \mathrm{~m}$ and $>500 \mathrm{~m}$ were established. The plot area was $250 \mathrm{~m} \times 250 \mathrm{~m}$ except above $500 \mathrm{~m}$, where it was smaller $(10 \times 10 \mathrm{~m})$. Trees selected to register lichens were Drypetes sepiaria and Ficus microcarpa at lower elevation $(<300 \mathrm{~m})$, Diospyros affinis and Dimocarpus longana at mid elevation (300-500 m) and Pterospermum suberifolium, Syzygium zeylanicum and Neolitsea cassia at high elevations $(<500 \mathrm{~m})$. Coverage and frequency of lichens were recorded by randomly placing a $250 \mathrm{~cm}^{2}$ quadrate on bole of each tree. Morphology, anatomy, reproductive structures and biochemistry of lichens were examined for their identification. Shannon's diversity index was used to determine the lichen diversities at different elevations. Data were statistically analysed to reveal the distribution pattern of lichens with change in elevation. Two hundred and eighty-six different lichens collected represented 27 families, 72 genera and 152 species. The distribution pattern of species reflected variability in environmental conditions at different elevations. Higher lichen diversities (1.48 and 1.45) were recorded at higher and lower altitudes than at mid altitudes (1.14). It is envisaged that microclimatic conditions at lower altitudes have encouraged the growth of lichens with trebouxioid photobionts, while shady and cooler niches supported those with cyanobacterial photobionts. Trentepohlioid lichens dominated at mid-elevations. At higher elevations, sunny locations encouraged the growth of trebouxioid folioses while shady and wet places supported cyanobacterial photobionts. Distinct species assemblages at different elevations showing restrictive species distribution signifies the need of protection of Ritigala SNR for lichen conservation.
\end{abstract}

Keywords: Altitudinal preferences, lichen diversity, Ritigala Strict Natural Reserve.

\section{INTRODUCTION}

Ritigala is the highest mountain range in the Anuradhapura district with the geographic coordinates $80^{\circ} 38^{\prime}-80^{\circ} 40^{\prime} \mathrm{E}$ and $8^{\circ} 0^{\prime}-8^{\circ} 9^{\prime} \mathrm{N}$ which is included under the Strict Natural Reserve category. It is situated $27 \mathrm{~km} \mathrm{~N}$ of Dambulla and $36 \mathrm{~km} \mathrm{SE}$ of Anuradhapura and covers an area of 1,528.2 ha. The terrain is hilly with an elevation of $766 \mathrm{~m}$ above sea level at the highest peak. This isolated hill ranges $6.5 \mathrm{~km}$ long on its northsouth axis and about $3 \mathrm{~km}$ wide at its widest point. It is divided into northern and southern blocks by the shallow Maha-Degala gorge (Central Cultural Fund, 1983). This isolated hill range is in the dry zone of the island where the climate is characterised by a bimodal pattern of rainfall and uniformly high temperature throughout the year. The total annual rainfall is around $1,500 \mathrm{~mm}$ and relative humidity ranges between $60 \%$ and $90 \%$. Prolonged dry period prior to the rainy season and desiccating winds during the long, hot south-west monsoon subject the vegetation to severe moisture stress.

Many botanists have studied the vegetation of Ritigala, commencing with Trimen in 1889 followed by Wills in 1906 and Jayasuriya in 1984. The vegetation of the area can be divided into several clear altitudinal zones: (i) Disturbed dry-mixed evergreen (lower

"Corresponding author (chandrani_wijeya@yahoo.com; (D https://orcid.org/0000-0001-5842-0997) 
elevation < $300 \mathrm{~m}$ ), (ii) Dry-mixed evergreen (oldgrowth) (middle elevation 300-500 m) and (iii) Shortstature forest (high elevation $>500 \mathrm{~m}$ ) occurring along the ridge tops (DWC, 2008). The dominant vegetation in Ritigala is dry-mixed evergreen forest. However, a clear altitudinal zonation is visible on the upper slopes except un-vegetated butte slopes on the eastern-side and on the summit of the reserve where one could observe a shortstature forest. This unique vegetation may be due to cloud cover and the mist that cloth the summit most of the year, which is closely comparable to the humid sub-montane and montane vegetation in the Highlands (DWC, 2008). According to Trimen (1889) the top of Ritigala represents 'a characteristic little oasis of vegetation distinct from the dry zone vegetation surrounding it'.

Understanding the diversity and distribution of organisms is the key aspect in conservation and management of a natural resource. Preliminary investigation on lichens in the area revealed that Ritigala hill range is not only distinct with respect to higher plants but also with respect to lichens. Seventeen species of lichens had been recorded by Jayasuriya (1984) in a study of the flora of Ritigala. Apart from that there are no published data on lichens of Ritigala. It is envisaged that there are patterns of lichen distribution and high species richness in this unique ecosystem.

The objectives of this study were (1) to understand and describe lichen diversity and distribution in this strict natural reserve in which the vegetation shows a clear pattern of altitudinal zonation (2) to suggest factors that may be important in influencing the distribution and abundance of lichens and (3) to provide baseline information with respect to corticolous and saxicolous lichens in areas that may be threatened by development activities such as extraction of phosphate deposit in the vicinity of Ritigala mountain range.

\section{METHODOLOGY}

\section{Study site}

Thirty four plots were established in Ritigala Strict Natural Reserve (Figure 1) at three elevations, covering three different forest types; dry mixed evergreen forest below $300 \mathrm{~m}$ with an open canopy (disturbed area), dry mixed evergreen forest with a fairly closed canopy between $300 \mathrm{~m}$ and $500 \mathrm{~m}$ elevation (undisturbed) and exposed mountain forest above $500 \mathrm{~m}$. At lower and mid

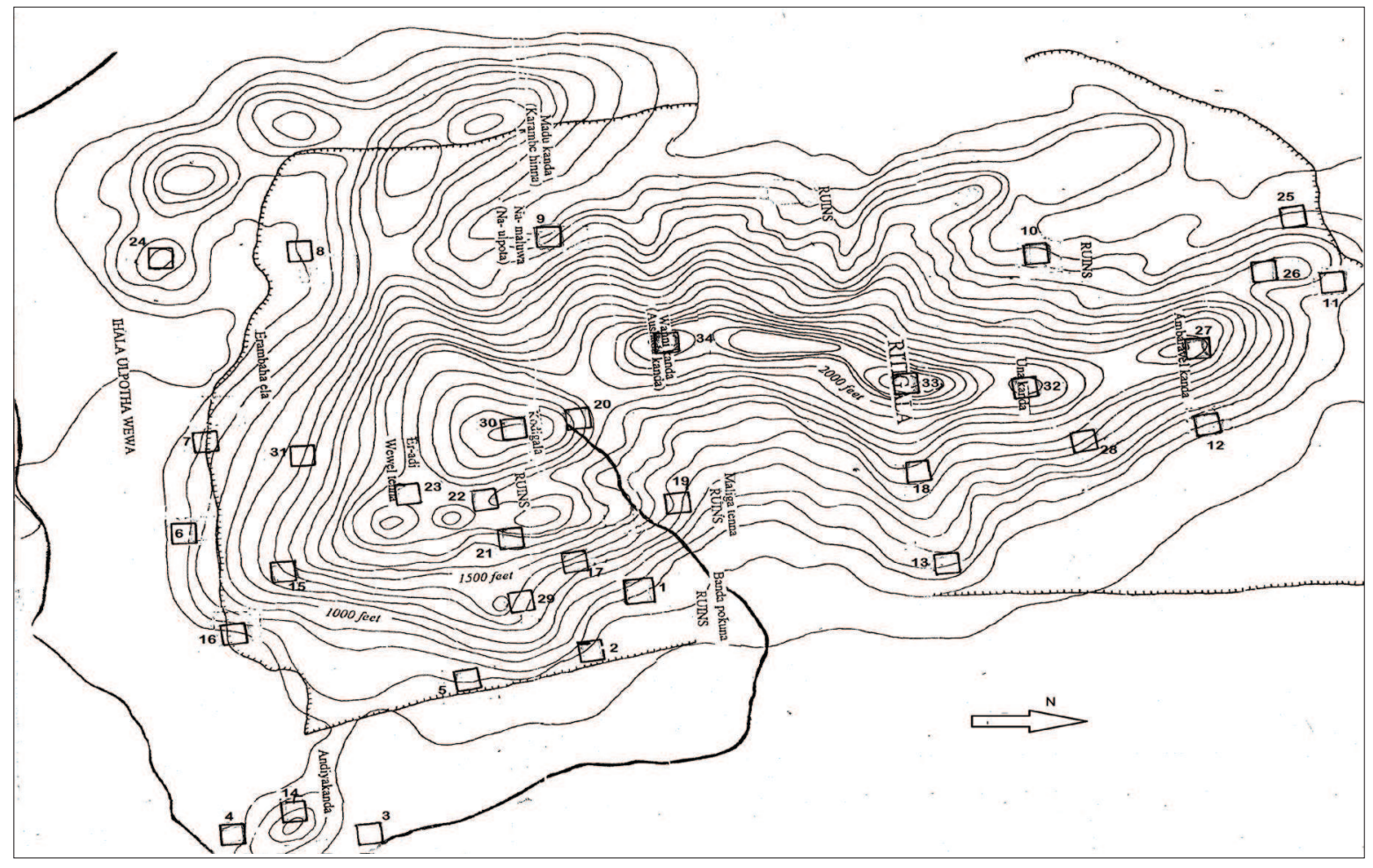

Figure 1: A contour map of Ritigala hill range depicting the 34 sites that were used in the lichen diversity monitoring study 
elevations the plot area was $250 \mathrm{~m} \times 250 \mathrm{~m}$ but above $500 \mathrm{~m}$ the plot area was smaller $(10 \times 10 \mathrm{~m})$ due to practical problems. Lichens were recorded on selected substrata (trees and rocks) at different elevations.

\section{Tree species examined for recording lichens}

The method used for recording of lichens was largely based on the German guidelines (VDI, 1995) with few modifications with respect to selection of sampling trees. By carrying out a preliminary investigation, trees that would be suitable for studying lichen diversity were selected by avoiding trees having peeling barks or grooved barks. Rocks were selected randomly to record lichens. This preliminary survey revealed that some tree species carried more lichens than others. Therefore, for registration of lichens at different elevations, trees having a greater diversity of lichens were selected. At lower elevation Drypetes sepiaria and Ficus microcarpa species and at mid elevation, Diospyros affinis and Dimocarpus longana, all of which had diameter at breast height $(\mathrm{DBH})$ great than $30 \mathrm{~cm}$ were selected to record lichen diversity. In each plot, three trees from each species were examined to record lichens. As occurrence of boulders and rocks carrying a great number of lichens were common in all sites, three rocks were also selected for examination of saxicolous lichens in each plot. As the vegetation changes at high elevations, Pterospermum suberifolium, Syzygium zeylanicum and Neolitsea cassia were examined to record lichens. As the DBH of these trees were less than $30 \mathrm{~cm}$, more trees were examined per plot. On short-stature trees, the lichen recording was done not only on the main stem but also on small branches and twigs.

\section{Registration of lichens}

For the registration of lichens on tree trunks, height between $0.5 \mathrm{~m}$ from the base to a height up to $1.5 \mathrm{~m}$ was selected as the sample area. Coverage and frequency of lichens were recorded by placing a $250 \mathrm{~cm}^{2}$ quadrate $(25 \mathrm{~cm} \times 10 \mathrm{~cm})$ randomly on the bole at four different places facing different aspects within the sampling area of each tree (Figure 2). On boulders, the quadrates were randomised with respect to aspect. In the case of shrubs, cover values of lichen taxa were calculated using the length of the twig and its average diameter. Each onemeter segment of a branch was considered as a micro plot. Twelve micro plots were considered as equivalent to one tree examined in a plot as the total circumference of 12 branches /twigs was roughly equal to $25 \mathrm{~cm}$, length of one side of the quadrate used.

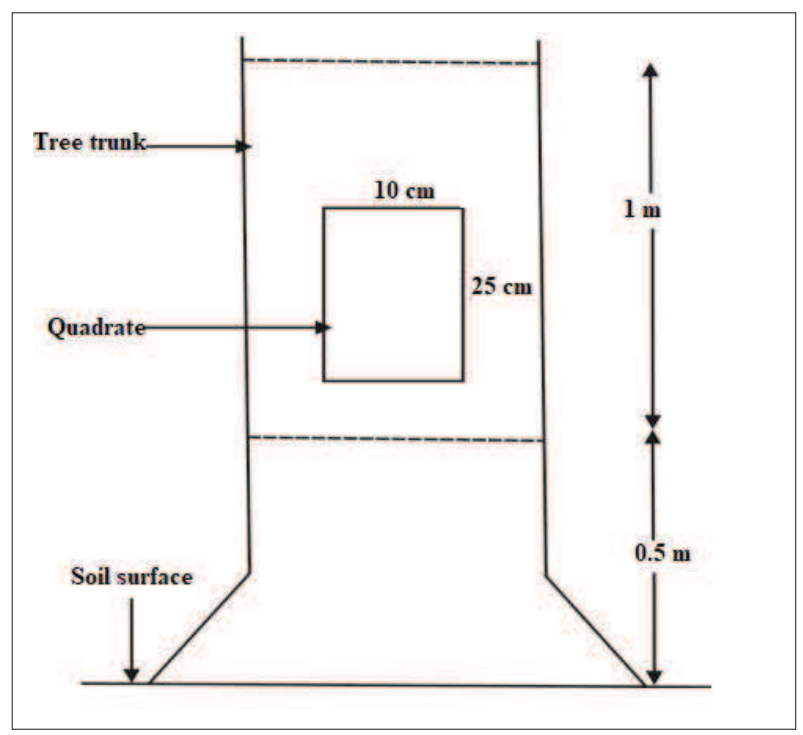

Figure 2: Registration of lichens on a tree trunk

\section{Measurement of bark pH}

The bark $\mathrm{pH}$ values of trees examined for lichens were determined using the method adopted by Farmer et al. (1990). Samples of bark were removed from each sampled tree at the height of about $1.5 \mathrm{~m}$ on the tree trunk. Two small pieces of bark with a total surface area of approximately $1 \mathrm{~cm}^{2}$ were cut from the collected samples and dipped in hot wax to expose only the outer surface. These waxed bark pieces were kept overnight in a $25 \mathrm{mmol} \mathrm{KCl}$ solution. Then the $\mathrm{pH}$ of the solution was determined after removing the bark pieces.

\section{Identification of lichens}

Microscopic examinations of the specimens were done with respect to morphology, anatomy and reproductive structures if present. Macro lichens that did not have reproductive structures were subjected to thin layer chromatograpy to obtain information with respect to their chemistry. After studying the morphological, reproductive and chemical characters, lichens were identified using standard taxonomic keys (Awasthi, 1988, 1991; Sipman, 1996).

\section{Lichen diversity}

Lichen diversity of each lichen community at different elevations was determined using Shannon's diversity index (Batten, 1976). 


$$
H^{\prime}=-\sum p_{i}\left(\log p_{i}\right)
$$

Where, $H^{\prime}=$ Diversity

$p_{i}=$ the proportional abundance of the $i^{\text {th }}$ site $=\mathrm{n}_{\mathrm{i}} / \mathrm{N}$.

$\mathrm{n}_{\mathrm{i}}=$ Number of species found in a site

$\mathrm{N}=$ Total number of species recorded in all sites of a particular elevation

Evenness $\mathrm{J}^{\prime}=\mathrm{H}^{\prime} / \mathrm{H}^{\prime} \max$

where $\mathrm{H}^{\prime} \max =\log \mathrm{N}$

Dominance $=1-\mathrm{J}$

\section{Lichen distribution in relation to exposure levels}

General exposure of the site to light was recorded as open, semi-shade or shade (categorised according to the observations) in the field. The three exposure levels were coded as, open-1; semi-shade-2; shade-3.

\section{Data analysis}

Diversity was measured as species richness and Shannon's Index was calculated for each lichen community at different elevations. Lichen coverage data of different elevations were analysed using one-way ANOVA at $5 \%$ level of significance to find out whether a correlation exists between coverage values and elevations.

\section{RESULTS AND DISCUSSION}

\section{Types of lichens recorded}

A total of 286 different lichens based on morphology, anatomy and reproductive structures were recorded during this study. Among the lichen growth forms, crustose lichens (65\% of all species) were predominant followed by foliose (29\%), fruticose and squamulose (3\% in both types) (Figure 3). These values are very much similar to values reported by Pinokiyo et al. (2008) for a protected biodiversity hot spot in north-east

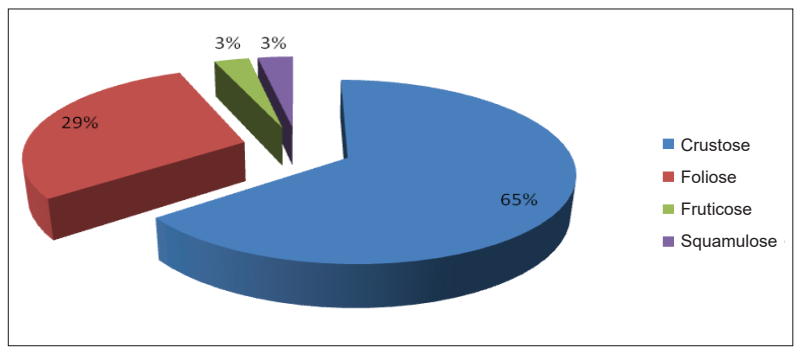

Figure 3: Percentages of different lichen types recorded in Ritigala mountain range
India. They recorded $56.5 \%$ crustose, $(34.5 \%)$ foliose, $8.5 \%$ fruticose and $0.6 \%$ squamulose in the area studied. Abundance of crustose species in several other protected areas in India has also been recorded by a number of researchers (Balaji \& Hariharan, 2004; Nayaka et al., 2004; Phatak et al., 2004).

\section{Identification of lichens}

Out of the total of 286 lichens, those which had either sexual or asexual structures were identified at least to the generic level and wherever possible to species level. These lichens represented 27 families, 72 genera and 152 identified species. It was not possible to identify sterile crustoses even to the genus level. Therefore, they were designated as sterile crustose with code numbers. This is the first instance that a high lichen diversity was recorded from a natural reserve in the Dry Zone of Sri Lanka. However, it should be emphasised that the number of species reported here are only corticolous and saxicolous lichens and the actual number of species would be much greater if the canopy is also examined. According to Cornelissen and Gradstein (1990), in tropical forests, $86 \%$ of macrolichens occurred exclusively in the canopy. Therefore, the recorded diversity in this study is a small part of the whole diversity. Nevertheless, total numbers of identified lichens signify that Ritigala SNR possesses a rich lichen diversity which may include new species. Of the thirty five species in Table 1 the first report of Thelotrema minisporum as a new species was by Wijeyaratne et al. (2012).

\section{Lichen diversity and their coverage values at different elevations}

Based on the percentage coverage values of lichen genera recorded, it was possible to put them into four categories; very common (percentage cover $>1$ ), common (percentage cover $0.99-0.5$ ), occasional (percentage cover $0.49-0.1$ ) and rare (percentage cover $<0.1$ ). Table 2 shows the genera and species that were recorded listed under these four categories.

Ecological factors play an important role in the growth, development, distribution and diversity of lichen species (Brunialti \& Giordani, 2003). Microclimatic conditions, particularly light, moisture and nutrients can influence distribution of lichens (Jonsson \& Jonsell, 1999). In Ritigala mountain range, the variation in the distribution of lichen species reflected variability in the environmental conditions at different elevations. At higher and lower elevations a greater lichen diversity was recorded than mid elevations (Table 3). 
Table 1: List of new records of lichens from Ritigala Strict Natural Reserve

\author{
Bulbothrix atrichella (Nyl.) Hale \\ Bulbothrix fungicola (Lynge.) Hale \\ Chiodectan leptosporum (Müll.) Arg. \\ Collema quadriloculare F. Wilson \\ Dichosporidium nigrocinctum (Ehrenb.) G. Thor. \\ Dirinaria complicata D.D. Awasthi \\ Dirinaria confluence (Fr.) D.D. Awasthi \\ Escatagonia prolifera (Mont.) R. Sant comb. Nov \\ Haematomma collatum ((Stirt) C. W. Dogge \\ Heterodermia obscurata (Nyl.) Trevisan \\ Lecanactis concordans (Nyl.) Zahlbr. \\ Leptogium marginellum (Swartz) S.F. Gray \\ Leptogium azureum (Sw. ex Ach.) Mont. \\ Letrouitia transgressa (Malme) Hafe. \& Bellem \\ Ocellularia allosporoides (Nyl.) Patw. \& Kulk. \\ Parmotrema andium (Müll. Arg.) Hale \\ Parmotrema durumae (Krog \& Swinscow) Krog \& Swinscow \\ Parmotrema gardneri (C.W. Dodge) Sérus \\ Parmotrema ravum (Krog \& Swinscow) Sérus \\ Parmotrema sulpuratum (Nees \& Flot.) Hale \\ Pertusaria granulate (Ach.) Mull. Arg. \\ Pertusaria kodaikalensis M. Choisy \\ Pertusaria quassiae (Fee.) Nyl. \\ Porina guentheri (Flot.) Zahlbr. \\ Porina nuculastrum (Müll.Arg.) R.C.Harris \\ Pyrenula carya R.C. Harris \\ Pyrenula kurzii Ajay Singh \& Upreti \\ Pyrenula nodulata (Stirt.) Zahlbr. \\ Pyrenula submarginata Vain. \\ Pyrenula subnitida Müll. Arg. \\ Pyxine austroindica D.D. Awasthi \\ Pyxine himalayensis D.D. Awasthi \\ Ramalina peruviana Ach. \\ Relicina abstrusa (Vain.) Hale \\ Roccella phycopsis (Ach.) \\ Thelotrema minisporum Wijeyaratne, Lucking \& Lumbsch sp. nov.
}

At lower elevation, the microclimate is hot and dry and trees received more light, encouraging the growth of photophilus lichen species with trebouxioid photobionts, e.g. Dirinaria spp., Parmotrema spp. (Figure 4a), and Pyxine spp. (Figure 4b), while lichens that have cyanobacterial photobionts, e.g. Leptogium cyanascence, (Figure 4c) and Parmeliella nigrocincta were confined to shady cool and moist places at lower elevations.

At mid elevation, light is a limiting factor due to the fairly closed canopy and high humidity (> $85 \%$ ) and provides conditions suitable for lichens with trentepohlioid photobionts such as Myriotrema spp., Thelotrema spp. (Figure 4d), Porina spp., Pyrenula spp. and Anthracothecium spp.. Considerable numbers of sterile crusts that were not identified to genera were recorded in majority of the sites in mid elevations. The lower diversity observed in mid elevation could be mainly due to the presence of sterile crustoses that were not identified to genus level, which covered large areas, mostly rock and boulders. Foliose lichens that were recorded in lower elevation sites were absent in the sites of mid elevation. However, fallen branches of trees of mid elevations revealed evidence for the presence of photophilous lichens such as Parmotrema spp., Rocella spp., Relicina spp. and Ramalina spp. in the canopy. According to Groombridge (1992) and Cornelissen and Gradstein (1990), in tropics the lichen biodiversity tends to be richest in the canopy vegetation.

The role of temperature and moisture on the diversity and distribution of lichens has been discussed by several researchers (Lesica et al., 1991; McCune \& Geiser, 1997; Pinokiyo et al., 2008). On Ritigala mountain range, at higher elevations $(>500 \mathrm{~m})$ the environment is cooler and fairly damp compared to any part of the dry zone which surrounds it. This unusual climate at higher elevations supports a wide variety of higher plant species quite distinct from the flat drier areas below draped with pendent masses of mosses and lichens similar to those in higher mountains (Wills, 1906). The short stature vegetation at higher elevations is due to the prevailing strong winds. Although ridge tops are exposed to sunlight at mid-day, mist and clouds envelop the crest in the evenings and at night, particularly during the south-west monsoon, ensuring high vapour condensation. Thus, during the early hours of the day, ridge tops are damp and cooler when compared to lower elevations. These unique microclimatic conditions at higher elevations support photophilus foliose and fruticose lichen genera with trebouxioid photobiont species: Heterodermia spp., Bulbothrix spp., Parmotrema spp. and Usnea spp., which are absent at lower elevation. Such epiphytic macrolichens are known for their drought tolerance and high light requirement (Pentecost, 1998). Lichens with cyanobacterial photobiont e.g. Pseudocephellaria sp., Sticta sp., Leptogium spp. and Coccocarpia spp. that are able to fix nitrogen were recorded in shady, cool and fairly wet places on rocks and on soil. The twigs and branches of short stature vegetation were mostly wrapped up with Collema sp., Coenogonium linkii and Heterodermia sp.. The findings of the present study agreed with the results and conclusions drawn from similar studies carried out in temperate and tropical countries (Wolseley \& AguirreHudson, 1997; Pinokiyo et al., 2008). 
Table 2: Lichen genera and species in four different categories: very common, common, occasional and rare based on the percentage cover

\begin{tabular}{|c|c|c|c|c|}
\hline \multirow{2}{*}{$\begin{array}{l}\text { Very common } \\
(\% \text { cover }>\mathbf{1})\end{array}$} & \multirow{2}{*}{$\begin{array}{l}\text { Common } \\
\text { (\% cover } 0.99 \text {-0.5) } \\
\text { Graphis } \text { sp. } 1\end{array}$} & \multicolumn{2}{|c|}{$\begin{array}{l}\text { Occasional } \\
(\% \text { cover } 0.49-0.1)\end{array}$} & \multirow{2}{*}{$\begin{array}{l}\text { Rare } \\
(\mathbf{\%} \text { cover }<\mathbf{0 . 1}) \\
\text { Bacidia } \text { sp. } 3\end{array}$} \\
\hline & & $\begin{array}{l}\text { Anthracothecium } \\
\text { subvenosum }\end{array}$ & Parmelia atrichella & \\
\hline Leptogium cynescens & Graphis sp. 2 & Bacidia corolloid & Parmelia fungicola & Byssaloma sp. \\
\hline Pseudocypellaria sp. & Dirinaria aegialita & Bacidia sp. 2 & Parmotrema andium & Collema pulcellum \\
\hline Phyllospora pannosa & Dirinaria picta & Buellia sp. 2 & Parmotrema complicata & $\begin{array}{l}\text { Collema } \\
\text { quadrilocularia }\end{array}$ \\
\hline $\begin{array}{l}\text { Arthopyrenia } \\
\text { ceylonensis }\end{array}$ & Graphis sp. 3 & Bulbothrix atrichella & Parmotrema gardneri & Gyrostomum sp. \\
\hline $\begin{array}{l}\text { Leptogium } \\
\text { denticulatum }\end{array}$ & Sticta sp. I & Canoparmellia sp. & Ocellularia orthomastia & $\begin{array}{l}\text { Heterodermia } \\
\text { obscurata }\end{array}$ \\
\hline Buellia posthabita & Graphina sp. 2 & Caloplaca sp. & Ocellularia sp. & Lecanora sufusca 1 \\
\hline Porina mastoidea & Hetrodermia diademata & Coccocarpia palmicola & Ochrolechia sp. & Leptogium azureum \\
\hline Porina luteopallens & Porina guentheri & Crustose & Parmotrema ravum & Lithothelium sp. \\
\hline $\begin{array}{l}\text { Myreotrema } \\
\text { glaucescens }\end{array}$ & Thelotrema sp. & Dirinaria papulifera & Pertusaria sp. & $\begin{array}{l}\text { Parmotrema } \\
\text { sulphuratum }\end{array}$ \\
\hline Porina tetracerae & Lecanora subfusca & Dirinaria complicata & Physcia dilatata & Parmelia isidiza \\
\hline Coenogonium linkii & Crustose (ash colour) & Drinaria sp.(isidia) & Physcia sp. 2(saxicolous) & Pertusaria isidiosa \\
\hline Aspicilia sp. & Crustose (white colour) & Graphis sp. 1 & Phyllospora sp. & Phaeographis sp. \\
\hline Lecanora subfusca & Lecanactis sp. & Graphina sp. & Porina sp. & Phaeographina sp. \\
\hline $\begin{array}{l}\text { Parmotrema } \\
\text { praesorediosum }\end{array}$ & Coccocarpia erythroxili & Haematomma collatum & Psilolechia sp. & Pyrenula sp. \\
\hline Pyxine subcinera & Dirinaria applantata & Heterodermia diademata & Pyrenula caryae & Pyxine coccifera \\
\hline Pyxine himalayensis & Myreotrema wightii & Heterodermia microphylla & Pyrenula kurzii & Heterodermia comosa \\
\hline Relicinopsis sp. & Crustose 12 & Heterodermia speciosa & Pyrenula nodulata & Toninia sp. \\
\hline Buellia sp. 2 & Crustose 14 & Heterodermia sp.(rock) & Pyrenula submarginata & Trypethelium eluteriae \\
\hline Pyrenula subnitida & Pyxine consocians & Lecidia sp. & Pyxine berteriana & \\
\hline Caloplaca sp. & Parmotrema durumae & Lecanactis sp. & Pyxine petricola & \\
\hline Lepraria sp. & Crustose (with isidia) & Lecanactis sp. (saxicolous) & Ramalina sp. & \\
\hline Graphina sp.1 & Sarcographae sp. & Lecanora subfusca & Ramalina peruviana & \\
\hline Graphis duplicata & Parmeliella nigrocincta & Leptogium juvanicum & Roccella montagnei & \\
\hline Pyrenula caryae & $\begin{array}{l}\text { Pertusaria } \\
\text { kodaikalensis }\end{array}$ & Leptogium marginellum & Roccella phycopsis & \\
\hline \multirow[t]{6}{*}{ Parmotrema tinctorum } & $\begin{array}{l}\text { Caloplaca sp. } \\
\text { Anthracothecium } \\
\text { pustuliferum }\end{array}$ & $\begin{array}{l}\text { Leptogium (isidia) sp. } \\
\text { Letrouitia domingensis }\end{array}$ & $\begin{array}{l}\text { Sticta weigelii } \\
\text { Thelotrema platysporum }\end{array}$ & \\
\hline & Parmotrema tabacina & Letrouitia transgressa & Thelotrema sp. & \\
\hline & Dirinaria confluens & Letrouitia vulpina & Trypethilium tropicum & \\
\hline & Haematomma sp. & Megalospora sp. & Xanthoparmelia sp. & \\
\hline & Phyllospora sp. 3 & Myreotrema sp. & & \\
\hline & Pyxine berteriana & & & \\
\hline
\end{tabular}


Table 3: Diversity indices of lichen communities at different altitudes of Ritigala SNR

\begin{tabular}{lccc}
\hline Elevation & Diversity & Evenness & Dominance \\
\hline High $>500 \mathrm{~m}$ & 1.48 & 0.92 & 0.08 \\
Mid $300-500 \mathrm{~m}$ & 1.14 & 0.82 & 0.18 \\
Lower $<300 \mathrm{~m}$ & 1.45 & 0.88 & 0.12 \\
\hline
\end{tabular}

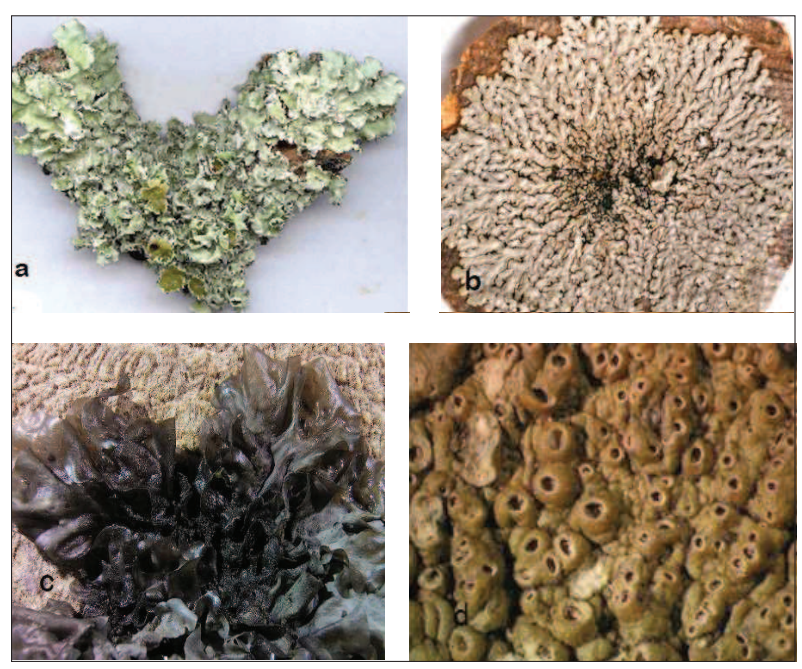

Figure 4: a) Parmotrema sp. and b) Pyxine subcinera, with Trebouxia as the photobiont; c) Leptogium cyanascens with Nostoc as the photobiont; d) Thelotrema minisporum with Trentepholia as the photobiont

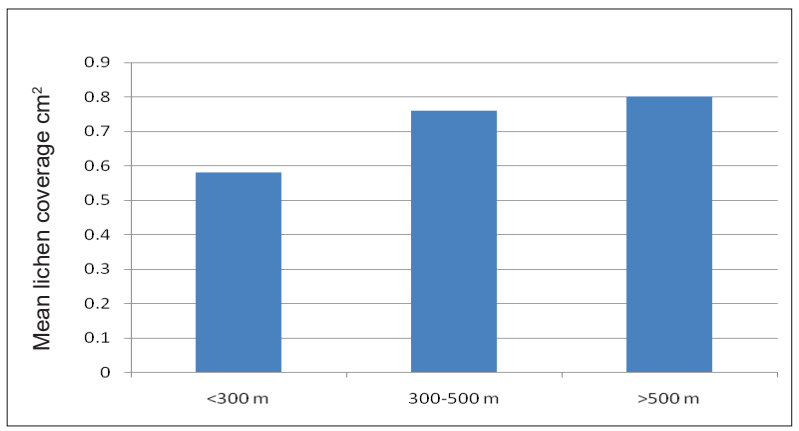

Figure 5: Lichen coverage at different elevations

When Pearson correlation coefficient was used at $1 \%$ level of significance, a positive correlation was found to exist between lichen coverage and the elevation. Lichen coverage increased with the increase in elevation
(Figure 5). One way ANOVA test performed at $5 \%$ level of significance revealed that there is no significant difference between the lichen diversity of low and higher elevations although the plot size was smaller and the DBH of trees were lesser in short stature forests at higher elevations $(>500 \mathrm{~m})$. The diversity of mid elevation was significantly different to those of lower and higher elevations (Table 3 ).

\section{Effect of Bark pH on lichen distribution}

The bark $\mathrm{pH}$ values of all trees used to monitor lichens were not significantly different and were all in the range 5-6. Therefore, the lichen community differences observed on different trees could not be due to the $\mathrm{pH}$ of barks of trees.

\section{Lichen coverage and exposure to light}

The trees examined for recording of lichens were categorised according to the degree of exposure to light. Thus, trees that were in open places, which received light almost equally throughout the day were included in the open category, those that did not get the full light regime in the semi-exposed category and those that were in shade most of the time in the shade category. There were no significant differences among the lichen coverages in the three different light regimes (open, semi and shade) when data were analysed using oneway ANOVA at $5 \%$ level of significance. While sites having different exposure levels were present across the elevational gradients, tree species composition and other environmental conditions mainly humidity varied across the elevation, which may have been important factors in the distribution and abundance of lichens in Ritigala mountain range.

\section{CONCLUSION}

Investigation of lichens of Ritigala mountain range revealed the presence of extremely interesting and remarkable diversity, which may not be seen anywhere else in Sri Lanka as their distribution strongly associated with elevation and other environmental gradients present. Presence of a large number of critical lichen families $(>50 \%)$ indicate that Ritigala is relatively undisturbed and embraces highly vulnerable lichen communities, which are susceptible to environmental changes.

The presence of distinct species assemblages at different elevations showing restricted species distribution signifies the need for protection of Ritigala Natural Reserve for lichen conservation. 
A study of canopy lichen diversity would enable a more accurate picture of the diversity and distribution in this unique biogeographic area, which is a strict natural reserve of Sri Lanka.

\section{Acknowledgement}

Authors wish to acknowledge the National Science Foundation (Grant No RG/99/B-4) and the University of Sri Jayewardenepura for providing financial assistance to carry out this research project. The second author acknowledges the Royal Society, United Kingdom for providing financial assistance to carry out the identification work at the British Natural History Museum. Assistance received from Ms. Patricia Wolseley, Life Science Department, Natural History Museum, London, UK in the identification of lichens is greatly acknowledged. The authors also wish to thank Ushan Chanaka for assistance provided in field work.

\section{REFERENCES}

Awasthi D.D. (1988). A key to the macro lichens of India, Nepal and Sri Lanka. Journal of the Hattori Botanical Laboratory 65: 207-302.

Awasthi D.D. (1991). A key to the micro lichens of India, Nepal and Sri Lanka. Bibliotheca Lichenologica 40:1-340.

Balaji P. \& Hariharan G.N. (2004). Lichen diversity and distribution patterns in tropical dry evergreen forest of Guindy National Park (GNP) Chennai. Indian Forester 130: $1155-1168$.

Batten L.A. (1976). Birds communities of some Killarney woodlands. Proceedings of the Royal Irish Academy 76: 285-313.

Brunialti G. \& Giordani P. (2003). Variability of lichen diversity in a climatically heterogeneous area (Ligaria, NW Italy) Lichenologist 35(1): 55-69. DOI: https://doi.org/10.1006/lich.2002.0417

Central Cultural Fund (1983). A Guide to Ritigala, Publication No. 13. Central Cultural Fund, Ministry of Cultural Affairs, Colombo, Sri Lanka.

Cornelissen J.H.C. \& Gradstein S.R. (1990). On the occurrence of bryophytes and macro-lichens in different lowland rainforest types at Mabura Hill Guyane. Tropical Bryology 3: $29-35$.

DOI: https://doi.org/10.11646/bde.3.1.4

Department of Wildlife Conservation (DWC) (2008). Biodiversity Baseline Survey: Ritigala Strict Natural Reserve, Consultancy Services Report. Ministry of Environmental and Natural Resources, Sri Lanka.

Farmer A., Bates J.W. \& Bell J.N.N. (1990). A comparison of methods for the measurement of bark $\mathrm{pH}$. Lichenologist 22 (2): 191-197.

DOI: https://doi.org/10.1017/S0024282990000147
Groombridge B. (1992). Global Biodiversity Status of the Earth's Living Resources. Chapman and Hall, London, UK.

Jayasuriya A.H.M. (1984). Flora of Ritigala Natural Reserve. The Sri Lanka Forester XVI(3\&4): 61-156.

Jonsson B.G. \& Jonsell M. (1999) Exploring potential of biodiversity indicator in boreal forests. Biodiversity and Conservation 8: 1417-1433. DOI: https://doi.org/10.1023/A:1008900309571

Lesica P., McCune B., Cooper S.V. \& Hong W.S. (1991). Difference in lichens and bryophyte communities between old-growth and managed second-growth forest in the Swan Valley Montana. Canadian Journal of Botany 69: 1745-1755.

DOI: https://doi.org/10.1139/b91-222

McCune B. \& Geiser L. (1997). Macro Lichens of the Pacific Northwest. Oregon State University Press, Corvallis, USA.

Nayaka S., Upreti D.K. \& Phatak S. \& Samuel C. (2004). Lichens of Bondla and Bhagwan Mahavir Wildlife sanctuaries, Goa. Biological Memoirs 30: 115-119.

Pentecost A. (1998). Some observations on the biomass and distribution of cryptogamic epiphytes in the upper montane forest of the Rwenzori Mountains, Uganda. Global Ecology and Biogeography Letters 7: 273-284.

DOI: https://doi.org/10.1046/j.1466-822X.1998.00297.x

Phatak S., Nayaka S., Upreti D.K., Singh S.M. \& Samuel C. (2004). Preliminary observations of lichens flora of Cotigao Wildlife Sanctuary, Goa, India. Phytotaxonomy 4: 104-106.

Pinokiyo A., Singh K.P. \& Singh J.S. (2008). Diversity and distribution of lichens in relation to altitude within a protected biodiversity hot spot, north-east India. Lichenologist 40(1): 47-62.

DOI: https://doi.org/10.1017/S0024282908007214

Sipman H. (1996). Key to the Lichen Genera of the Guianas. Available at http://www.nmnh.si.edu/biodiversity/ lichkey2htm, Accessed 10 August 2000.

Trimen H. (1889). Note on the botany of Ritigala. Journal of the Royal Asiatic Society Ceylon Branch of the XI No. 39.

Verein Deutscher Ingeniure (VDI) (1995). Measurement and evaluation of phytotoxic effects of ambient air pollutants (immissions) with lichens; Mapping of lichens for the assessment of air quality. VDI Richtlinien 3799 Part 1, Berlin

Wijeyaratne S.C., Lucking R. \& Thorsten H.T. (2012). Three crustose lichen species from Sri Lanka. Nova Hedwigia 94(3-4): 367-372.

DOI: https://doi.org/10.1127/0029-5035/2012/0008

Wills J.C. (1906). The flora of Ritigala, an isolated mountain in the North Central Province of Ceylon: a study in endemism. Annals of the Royal Botanical Gardens Peradeniya 8: 271-301.

Wolseley P.A. \& Aguirre-Hudson B. (1997). The ecology and distribution of lichens in tropical deciduous and evergreen forests of northern Thailand. Journal of Biogeography 24: 327-343.

DOI: https://doi.org/10.1046/j.1365-2699.1997.00124.x 